\title{
Environmental Impacts of Industrial Liquid Discharges from the Food Alcohol Production Plant on the Waters of the Klou River of Logozohè in Benin
}

\author{
Akotegnon Calixte Koffi ${ }^{1,2}$, Gbaguidi Acakpo Nonvignon Magloire ${ }^{1, ~ *, ~}$ \\ Dovonon Léonce Firmin Comlan ${ }^{1}$, Hounaho Grâce-Félix ${ }^{1}$, Zannou Aimé1 ${ }^{1}$, Kpognon Elias ${ }^{3}$, \\ Adanho Hermione ${ }^{2}$, Amoussou-Chouh Olivia ${ }^{2}$, Moussoro Samson ${ }^{2}$ \\ ${ }^{1}$ Research Unit in Ecotoxicology and Quality Studies (UREEQ), Laboratory for Research and Studies in Applied Chemistry (LERCA), \\ Polytechnic School of Abomey-Calavi (EPAC), University of Abomey-Calavi (UAC), Cotonou, Republic of Benin \\ ${ }^{2}$ Central Laboratory of the National Water Company of Benin (SONEB), Cotonou, Republic of Benin \\ ${ }^{3}$ Central Laboratory of Water Quality and Food Control of the Ministry of Health (LCQECA/MS), Cotonou, Republic of Benin
}

Email address:

calixte_akotegnon_66@yahoo.fr (A. C. Koffi), gbmag3@yahoo.fr (G. A. N. Magloire), ldovonon@yahoo.fr (D. L. F. Comlan), graceflix@gmail.com (H. Grâce-Félix), aimezannou52@gmail.com (Z. Aimé) pognonelias@yahoo.fr (K. Elias),

dosslinaur@gmail.com (A. Hermione), amoussouahounou@gmail.com (Amoussou-Chouh O.),

amoussouchouh@yahoo.fr (Amoussou-Chouh O.), amoussouchouholivia@yahoo.fr (Amoussou-Chouh O.),

roksams@gmail.com (M. Samson )

${ }^{*}$ Corresponding author

To cite this article:

Akotegnon Calixte Koffi, Gbaguidi Acakpo Nonvignon Magloire, Dovonon Léonce Firmin Comlan, Hounaho Grâce-Félix, Zannou Aimé, Kpognon Elias, Adanho Hermione, Amoussou-Chouh Olivia, Moussoro Samson. Environmental Impacts of Industrial Liquid Discharges from the Food Alcohol Production Plant on the Waters of the Klou River of Logozohè in Benin. American Journal of Applied Chemistry. Vol. 6, No. 5, 2018, pp. 156-168. doi: 10.11648/j.ajac.20180605.11

Received: August 31, 2018; Accepted: September 14, 2018; Published: November 15, 2018

\begin{abstract}
This study aims the evaluation of environmental impacts of dusty fluid on the production of nutriment alcohol at Logozohè through a physico-chemical settings of its components and an assessment of it impact on river Klou which is the fallen point. Then, twenty-two (22) skills were measured through the normative methods on eight (08) areas along the Klou river from the upstream to the downstream around the production land in 2017; August 25 ${ }^{\text {th }}$ to 28th.. Data were submitted to descriptive and statistical analysis and a Main Components Analysis made with Minitab 14. Results reveal that the $\mathrm{pH}$, turbidity, suspended matter (SS) and COD of the principal effluent and Klou river do not meet drinking and wastewater water quality standard for Republic of Benin. But nitrogen pollution is low and it's reduced to kjeldahl nitrogen (NTK). Organic pollution is very important and not biodegradable. This leads to suspicion of the use of synthetic organic solvents in the processes of the production unit. Conclusion: This massive organic pollution of the receiving environment on which local residents depend challenges more than one of the environmental impact of the food alcohol production plant on the future of the Klou river.
\end{abstract}

Keywords: Pollution, Water, Klou, Effluent, Industry, Agribusiness

\section{Introduction}

The first men, few in number and devoid of technical means, lived for a long time in harmony with their environment, like other animals [1]. The transition from the Paleolithic to the Neolithic with the sedentary lifestyle and the first agricultural revolution profoundly disturbed this initial balance [2]. Subsequently, we have witnessed the population growth and industrial development, which have worsened the degradation of all environmental components [3]. Thus, the race to economic growth is engaged with a strong consumption of raw materials, the degradation of the living environment with rejections of all 
kinds and many consequences on the nature, its resources and indirectly on the Man [4]. In addition, the industry has often favored sites near water bodies such as rivers, oceans and seas for the transportation of raw materials, for water supply and for discharges of industrial effluents [3, 5]. Thus, for decades, rivers and oceans have been the receptacle of industrial direct discharges, victims of accidental spills and/or polluted by runoff that leached from contaminated areas $[6,7]$. This is the case in Benin of a Chinese food production plant based on cassava chips set up near the Klou river located in the district of Logozohè, commune of Savalou from where it draws a portion of its water needs and rejects its industrial effluents. After about ten years of activity, we are witnessing today an advanced and continuous degradation of a portion of the watercourse on which often depend the peasant riverside populations. The incessant aggravation of the pollution to the detriment of the populations (human, animal and vegetable) subservient to the watercourse pushed us to seek the environmental impacts of the liquid discharges of the food alcohol production plant on the waters of the Klou river of Logozohè.

\section{Material and Methods}

\subsection{Presentation of the Study Area}

The framework of our study is the Klou River, specifically the watershed from the Klou spring to the outlet of the Logozohè bridge located between $07^{\circ} 53,199{ }^{\prime} \mathrm{N}$ and $002^{\circ} 05,995^{\prime} \mathrm{E}$. It covers part of the communes of Savalou and Glazoué. Its altitude varies from $215 \mathrm{~m}$ from the source to $140 \mathrm{~m}$ at the outlet of Logozohè for an average altitude of
$154.71 \pm 21.96$. The average elevation of the Klou catchment is $178.1 \pm 19.9 \mathrm{~m}$ [7]. This region benefits from a humid tropical transition or Sudano-Guinean climate [8], belonging to a region subject to both equatorial influences and Guinean alternating regime influences. This region benefits from a humid tropical transition or Sudano-Guinean climate [8], belonging to a region subject to both equatorial influences and Guinean alternating regime influences. The average rainfall is $1150 \mathrm{~mm}$, varying between 864 and $1637.3 \mathrm{~mm}$ between years. Temperatures are high all year round with minima ranging from 23 to $24^{\circ} \mathrm{C}$ and maxima ranging from 35 to $36^{\circ} \mathrm{C}$ [9]. Its relief is based on material Its rainfall pattern characterized by a distribution of rains marked by the appearance of two rainy seasons from March to July and from September to November; from two dry seasons from December to March and the month of August which corresponds to the decrease of precipitations precambrian granite-gneiss of the old base. These are metamorphic rocks marked by magmatic intrusions (granites). The relief culminates between 120 and $500 \mathrm{~m}$ with slopes varying between 3 and $10 \%$ in the agglomerated sites. The most common soils are tropical ferruginous soils with areas of concretion. There are also hydromorphic soils, vertisols [9].

\subsection{Choice of Sampling Sites}

The sites were selected from upstream to downstream of the plant according to a sampling plan (Table 1) in order to evaluate the quality of the water before and after the rejections of the plant.

Table 1. Sampling Sites and Geographic Coordinates.

\begin{tabular}{|c|c|c|c|}
\hline $\mathbf{N}^{\circ}$ & Denomination of the sites & Codes & Geographic coordinates \\
\hline 1 & $\begin{array}{l}\text { Site } 1 \text { "Source Klou" is located between the Aklampa village and Yagbo behind the village of Zoungoudo. } \\
\text { It is here that the Klou river rises in the middle of rice and yam fields. }\end{array}$ & ST 1 & $\begin{array}{l}08^{\circ} 07.209^{\prime} \mathrm{N} \\
002^{\circ} 08.012^{\prime} \mathrm{E} \\
\text { Alti }: 215 \mathrm{~m}\end{array}$ \\
\hline 2 & $\begin{array}{l}\text { Site } 2 \text { located at the bridge between Ouèdèmè (common Glazoué) and Lahotan (common Savalou) as } \\
\text { indicated by the name given to the site. Sampling was done on the left side under the bridge towards } \\
\text { Lahotan. }\end{array}$ & ST 2 & $\begin{array}{l}08^{\circ} 00.830^{\prime} \mathrm{N} \\
002^{\circ} 06.915^{\prime} \mathrm{E} \\
\text { Alti : } 179 \mathrm{~m}\end{array}$ \\
\hline 3 & $\begin{array}{l}\text { Site } 3 \text { or site of the Klou Dam. Sampling was done at the weir of the dam. It represents the receptacle of } \\
\text { the waters of the river klou just before the mouth between the effluent of the plant and the river. }\end{array}$ & ST 3 & $\begin{array}{l}07^{\circ} 53.270^{\prime} \mathrm{N} \\
002^{\circ} 06.098^{\prime} \mathrm{E} \\
\text { Alti : } 159 \mathrm{~m}\end{array}$ \\
\hline 4 & $\begin{array}{l}\text { Site } 4 \text { is located at the main liquid effluent of the plant. This is the place of the wastewater receptacle of } \\
\text { the plant. Site } 4 \text { is used to evaluate the gross pollutant characteristics released by the plant before any } \\
\text { contact with the waters of the Klou river. }\end{array}$ & ST 4 & $\begin{array}{l}07^{\circ} 53.254^{\prime} \mathrm{N} \\
002^{\circ} 06.004^{\prime} \mathrm{E} \\
\text { Alti : } 130 \mathrm{~m}\end{array}$ \\
\hline 5 & $\begin{array}{l}\text { Site } 5 \text { is the point of contact between the Klou river and the effluent from the plant. Sampling was done in } \\
\text { the sewage trench at the mouth of the liquid effluent and the Klou river. }\end{array}$ & ST 5 & $\begin{array}{l}07^{\circ} 53.247^{\prime} \mathrm{N} \\
002^{\circ} 06.018^{\prime} \mathrm{E}\end{array}$ \\
\hline 6 & Site 6 is located in the Klou river at the mouth about $1 \mathrm{~m}$ after site 5 & ST 6 & Alti : $130 \mathrm{~m}$ \\
\hline 7 & $\begin{array}{l}\text { Site } 7 \text { is located after the mouth of the effluent where the wastewater is mixed with water from the Klou } \\
\text { river from the dam to the Klou Bridge }\end{array}$ & ST 7 & $\begin{array}{l}07^{\circ} 53.240^{\prime} \mathrm{N} \\
002^{\circ} 06.016^{\prime} \mathrm{E} \\
\text { Alti : } 131 \mathrm{~m}\end{array}$ \\
\hline 8 & $\begin{array}{l}\text { Site } 8 \text { is located after the Logozohè bridge. It is another receptacle of Klou water and effluents from the } \\
\text { alcohol production plant. This is one of the pockets of water in the dry season. }\end{array}$ & ST 8 & $\begin{array}{l}07^{\circ} 53.199^{\prime} \mathrm{N} \\
002^{\circ} 05.995^{\prime} \mathrm{E} \\
\text { Alti : } 140 \mathrm{~m}\end{array}$ \\
\hline
\end{tabular}

\subsection{Sampling of Water}

This study was the subject of a single campaign carried out in the rainy season from 25 to 28 August 2017. All the water samples were recovered in plastic bottles of $1.5 \mathrm{~L}$ mineral water previously emptied, soaped without detergent and 
rinsed three times with distilled water. Before any sampling. The vials thus conditioned are rerinced three times with the water to be sampled. Samples are collected in the water column about $5 \mathrm{~cm}$ from the surface. After sampling, the vials are labeled and stored in a cooler equipped with a cold accumulator and sent to the laboratory at $4^{\circ} \mathrm{C}$ until analysis.

\subsection{Physico-chemical Analysis Methods}

Parameters such as $\mathrm{pH}$, temperature, electrical conductivity, dissolved total solids (TDS), salinity and dissolved oxygen were measured in situ according to standard NF EN 25814 using a multi parameter type Aqualyse Professional Plus YSI. The Winkler and Aquamerck Kit 1.11136.0001 were used respectively for the measurement of dissolved oxygen and total iron in situ by chemical means. Table 2 presents the standard methods used to determine the parameters for determining the physicochemical characteristics of the water of the klou river.

Table 2. Standard Methods Used to Determine Laboratory Parameters.

\begin{tabular}{|c|c|c|}
\hline $\begin{array}{l}\text { Different } \\
\text { parameters }\end{array}$ & Principle of the method & $\begin{array}{l}\text { Reference of the } \\
\text { method }\end{array}$ \\
\hline $\mathrm{NH}_{4}^{+}$ & $\begin{array}{l}\text { Formation in an alkaline medium of an indophenol compound by reaction of } \mathrm{NH}_{4}{ }^{+} \text {with phenol and } \mathrm{ClO} 3 \text { in the } \\
\text { presence of nitroprusside } \mathrm{Na}_{2}\left[\mathrm{Fe}(\mathrm{CN})_{5} \mathrm{NO}\right] \cdot 2 \mathrm{H}_{2} \mathrm{O} \text { as a catalyst gives a blue indophenol color. spectrophotometric } \\
\text { measurement at } \lambda=630 \mathrm{~nm}\end{array}$ & NFT90-015-2 \\
\hline $\mathrm{NO}_{2}^{-}$ & $\begin{array}{l}\text { The method is based on the reaction of } \mathrm{NO}_{2}^{-} \text {ions with } 4 \text {-aminobenzene sulfonamide at } \mathrm{pH}=1.9 \text { in the presence } \\
\text { of de } \mathrm{H}_{3} \mathrm{PO}_{4} \text { to form a diazo salt which complexes with } \mathrm{N} \text { - (Naphtyl-1) diamino dihydrochloride 1,2-ethane to } \\
\text { give a pink color whose intensity is proportional to the } \mathrm{NO}_{2}^{-} \text {content and measurable at } 540 \mathrm{~nm}\end{array}$ & NF EN 26777 \\
\hline $\mathrm{SO}_{4}{ }^{2-}$ & $\begin{array}{l}\text { Precipitation of the sulphate ions by } \mathrm{BaCl}_{2} \text { in a hydrochloric medium in the form of stabilized } \mathrm{BaSO}_{4} \text { by a } 25 \% \\
\text { solution of polyvinylpyrrolidone and nephelometric measurement at } 650 \mathrm{~nm} \text {. }\end{array}$ & NF T 90-040 \\
\hline P total & $\begin{array}{l}\text { The method relies on the reaction of } \mathrm{H}_{3} \mathrm{PO}_{4} \text { ions with an acid solution containing molybdate and antimony ions to } \\
\text { form an antimonyl phosphomolybdate complex which is reduced by ascorbic acid in bright-colored molybdenum } \\
\text { blue measurable at } 700 \mathrm{~nm} \text {. }\end{array}$ & $\begin{array}{l}\text { NF EN ISO } 6878 \\
(\text { T90-023) }\end{array}$ \\
\hline $\mathrm{Cl}^{-}$ & $\begin{array}{l}\text { Reaction of } \mathrm{Cl} \text { - ions with } \mathrm{Ag}^{+} \text {ions to form insoluble } \mathrm{AgCl} \text {. Addition of a small excess of } \mathrm{Ag}+\text { to give } \\
\text { reddishcolored Agent Chromate in the presence of the chromate ions used as an indicator reaction } \mathrm{pH} \text { of between } \\
5 \text { and 9.5. }\end{array}$ & NF ISO 9297 \\
\hline $\mathrm{TH}$ & $\begin{array}{l}\text { Complexation of } \mathrm{Ca}^{2+} \text { and } \mathrm{Mg}^{2+} \text { ions using EDTA at } \mathrm{pH} 10 \text {. And assay in the presence of Eriochrome Black T as } \\
\text { an indicator }\end{array}$ & NF T90-003 \\
\hline TAC & Titration of a sample of water to be analyzed by a $0.02 \mathrm{~N}$ acid solution at $\mathrm{pH}=5.4$ & NF EN ISO 9963-1 \\
\hline COD & $\begin{array}{l}\text { Acid Oxidation of Organic Matter by Excess } \mathrm{K}_{2} \mathrm{Cr}_{2} \mathrm{O}_{7} \text { in the Presence of } \mathrm{AgSO}_{4} \text { as Catalyst and } \mathrm{HgSO}_{4} \text { to } \\
\text { Complexe } \mathrm{Cl}^{-} \text {and Determination of Excess Oxidant with Mohr Salt Solution }\left(\mathrm{NH}_{4} \mathrm{Fe}\left(\mathrm{SO}_{4}\right)_{2} .6 \mathrm{H}_{2} \mathrm{O}\right)\end{array}$ & NF T90-101 \\
\hline $\mathrm{BOD}_{5}$ & $\begin{array}{l}\text { Oxidation of the biodegradable organic matter contained in a water sample by natural microorganisms in the dark } \\
\text { in amber bottles saturated with } \mathrm{O}_{2} \text { placed in a thermostatic incubator at } 20^{\circ} \mathrm{C} \pm 2^{\circ} \mathrm{C} \text { for } 5 \text { days }\end{array}$ & NF EN 1899-2 \\
\hline MES & $\begin{array}{l}\text { Filtration of water on fiberglass filter and then dried at } 105 \pm 2^{\circ} \mathrm{C} \text { and gravimetric determination by mass } \\
\text { difference }\end{array}$ & NF EN 872 \\
\hline Turbidity & $\begin{array}{l}\text { Radiation emission of } \lambda=860 \mathrm{~nm} \text { in a sample and measurement of scattered radiation transmitted by suspended } \\
\text { particles }\end{array}$ & NF EN ISO 7027 \\
\hline $\mathrm{O}_{2}$ dissolved & $\begin{array}{l}\text { Immersion of a probe consisting of a closed cell by a dissolved membrane permeable to } \mathrm{O}_{2} \text { dissolved and } \\
\text { containing the electrolyte and two metal electrodes in the water to be analyzed. }\end{array}$ & NF EN 25814 \\
\hline Total iron & $\begin{array}{l}\text { Transform and / or maintain the iron contained in a Fe II water sample by acidification of the sample. The } \\
\text { buffered medium at a } \mathrm{pH} \text { of } 4.5 \text { with a solution of } \mathrm{CH} 3 \mathrm{COONH} 4-\mathrm{CH}_{3} \mathrm{COOH} \text {. Complex the dissolved iron with } \\
\text { hydroxylamine hydrochloride solution in the presence of } 1,10 \text {-phenanthroline which develops a measurable } \\
\text { orange-red color at } 510 \mathrm{~nm}\end{array}$ & NF T90-017 \\
\hline
\end{tabular}

Determination of the ion Nitrate $\mathrm{NO}_{3}{ }^{-}$

In the presence of sodium salicylate, the nitrates give the yellow-colored sodium paranitrosalicylate which is capable of a colorimetric determination at $520 \mathrm{~nm} \mathrm{[10].} \mathrm{For} \mathrm{all}$ spectrophotometric methods, the Lovibond Spectro II-4C Spectrometer was used. For BOD5, the respirometric method with Oxitop BOX WTW $\mathrm{R}$ in a 12-station thermostatic chamber was used.

\subsection{Statistical Analyzes}

The data from the laboratory analysis as well as those taken or measured in the field were the subject of a descriptive statistic in which the means and standard deviations of the data of the different sites studied were calculated. The description of the links between the chemical characteristics of the pollutants of the river in the rainy season was made by a Principal Component Analysis. Excel and Minitab 14 software were used.

\section{Results and Discussion}

\subsection{Spatial Variations of Physicochemical Parameters}

\subsubsection{Temperature and Hydrogen Potential (pH)}

Figure 1 shows the variation in water temperature at the sites sampled during the campaign. From the analysis of the graph, it appears that the temperature varies between 24.9 and $30.9^{\circ} \mathrm{C}$ with an average of $26.76 \pm 0.90^{\circ} \mathrm{C}$. The lowest value of the temperature is observed at the ST3 site while the highest value is observed at the ST4 site. The coefficient of variation $(\% \mathrm{CV})$ of the temperature is 9.54 lower than 10 , showing that the temperature data are homogeneous. Despite this homogeneity of the temperature data, it should be noted 
that the hottest points are at the main effluent and the confluence zone between the main effluent and the river water. Temperature differences between the Klou river water and the plant effluent are around $6^{\circ} \mathrm{C}$. However, wastewater discharge standards in the Republic of Benin recommend variations of less than or equal to $5^{\circ} \mathrm{C}$ [11]. Our average temperature value is higher than that obtained by [12] who worked in the Ouémé Delta basin with temperature averages of 22 and $26.20 \pm 0.47^{\circ} \mathrm{C}$. Our maximum value is close to $30.5^{\circ} \mathrm{C}$ found by the same authors in this area (Ouémé Basin). On the other hand, these average values are lower than those obtained by [4] whose average values are $27.9 \pm$ 0.86 and $28.1 \pm 0.95^{\circ} \mathrm{C}$, with maxima respectively 28.9 and $29.4^{\circ} \mathrm{C}$ in the same zone as [12]. These observed variations in the temperature measurement would be related to several climatic parameters such as sunshine, the rainy season and the time of day when the measurement was made. However, it should be noted that [12] worked exclusively on surface water, as did the present study, while the [4] studies focused on both surface water and groundwater.

Figure 2 shows the change in $\mathrm{pH}$ of the water at the sites sampled during the campaign. From the analysis of the graph, it appears that the $\mathrm{pH}$ varies between 5.32 and 7.52 with an average of $6.92 \pm 0.27$. The lowest $\mathrm{pH}$ value is observed at the ST4 site (main effluent) while the highest value is observed at the ST2 site (Ouèdèmè-Lahotan bridge site). The coefficient of variation (\% CV) of the $\mathrm{pH}$ which is $11.1(10 \leq \% \mathrm{CV} \leq 30)$ shows that the homogeneity of the $\mathrm{pH}$ data is acceptable. The average of our $\mathrm{pH}$ values is higher than those obtained by [12] and [4] whose values vary respectively between $6.62 \pm 0.6$ and $6.39 \pm 0$. 8. Our maximum value is close to those obtained by these authors (respectively 7.5 and 7.3). The recommended $\mathrm{pH}$ values for surface water are between 6.5 and 9 [10]. No site has a $\mathrm{pH}$ greater than 9. However, the $\mathrm{pH}$ of the main effluent is less than 6 , which is contrary to the normative requirements of Benin [11]. $\mathrm{pH}$ depends on carbon balance and photosynthetic activity of ecosystems. $\mathrm{pH}$ conditions bacterial growth. Nitrifying bacteria require $\mathrm{pHs}$ between 7.4 and 9 for Nitrosomonas, 8.5 and 9.1 for Nitrobacter; in contrast, the Acinetobacter dephosphating bacteria thrive further at more acidic $\mathrm{pHs}$, ranging from 6.1 to 7.5 [4].
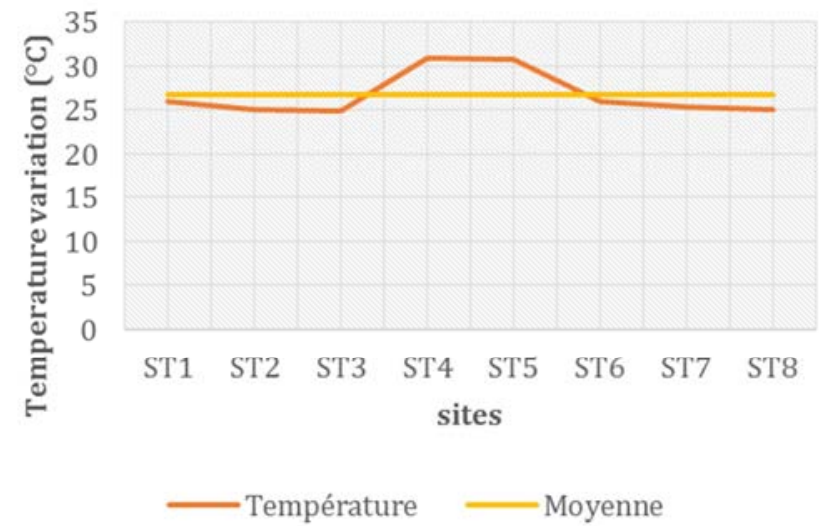

Figure 1. Spatial temperature variation in the sampling area.

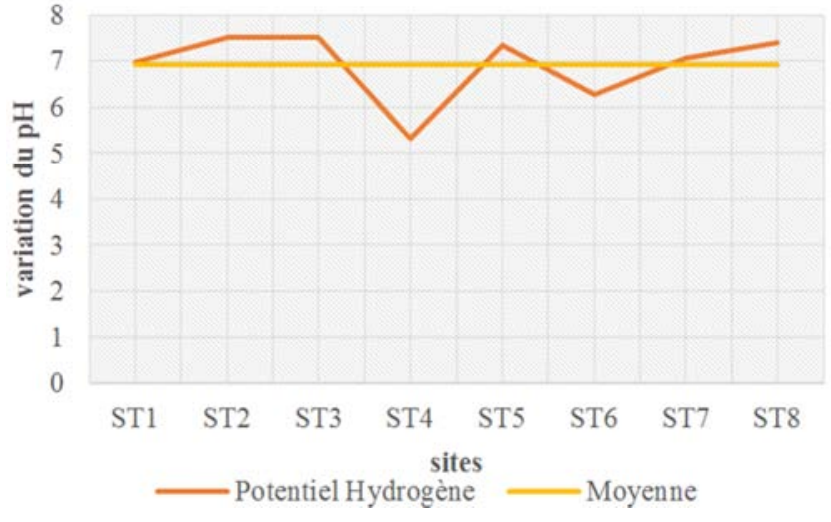

Figure 2. Spatial variation of the $\mathrm{pH}$ of the water in the sampling area.

\subsubsection{Electrical Conductivity and Turbidity of Water}

Figure 3 shows the variation of the electrical conductivity of the water at the sites sampled during the campaign. From the analysis of the graph, it appears that the electrical conductivity varies between 51.4 and $470 \mu \mathrm{S} / \mathrm{cm}$ with an average of $185.23 \pm 61.10 \mu \mathrm{S} / \mathrm{cm}$. The lowest value of electrical conductivity is observed at the ST1 site while the highest value is observed at the ST4 site. The coefficient of variation $(\% \mathrm{CV})$ of the conductivity is 93.3 showing a disparity between the conductivity data. The disparity noted is mainly due to the high conductivities of the effluents of the plant which are more than 5 times the electrical conductivity of the waters of the receiving environment. Our extreme values (minimum and maximum) are respectively lower and higher than those obtained by [12] which are respectively 59.8 and $238 \mu \mathrm{S} / \mathrm{cm}$. All these values obtained are lower than the recommended limit value for freshwaters of $2000 \mu \mathrm{S} / \mathrm{cm}$ [11].

Figure 4 shows the variation in turbidity of water at the sites sampled during the campaign. From the analysis of the graph, it appears that the turbidity varies between 134 and 1313 NTU with an average of $401.75 \pm 136.46$ NTU. The lowest value of turbidity is observed at the ST1 site while the highest value is observed at the ST5 site. The coefficient of variation (\% CV) of the turbidity is 96.07 . This\% CV value shows a dispersion of the data. This dispersion is created by the high turbidity value recorded at the ST5 site, which is more than four times the turbidity recorded at the ST3 site located in the river before the confluence zone. This local observation of turbidity is due to a swirling of the water at the meeting point of the two water masses which resuspends the surface sediments. Our extreme values (minimum and maximum) and our average are much higher than those obtained by [4] which are respectively from 2 to $100 \mathrm{NTU}$ for the first campaign with an average of $43.15 \pm 32.1 \mathrm{NTU}$ and 3 to 326 NTU for the 2nd season with an average of $103.54 \pm 91.54$ NTU. The maximum value recommended by the World Health Organization (WHO) for drinking water is 5 NTU [13]. All values obtained are above WHO allowable values, indicating that the waters of the sampled sites are unfit for consumption, except after adequate treatment that lowers its turbidity. 


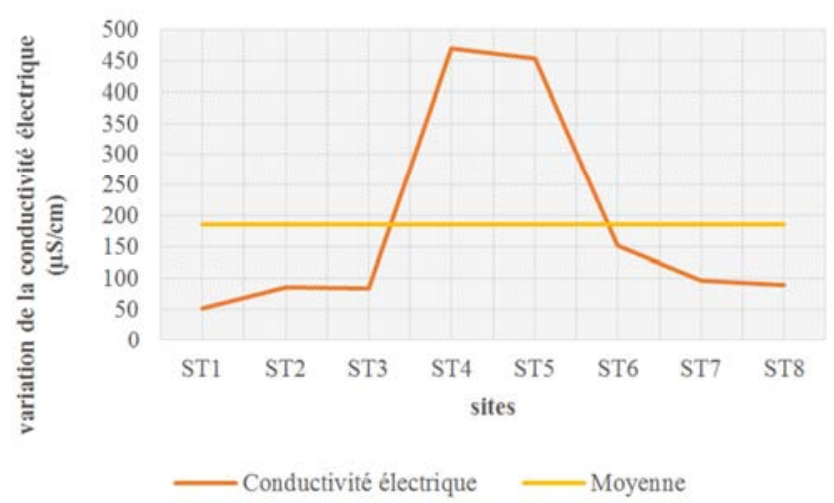

Figure 3. Spatial variation of electrical conductivity of water in the sampling area.

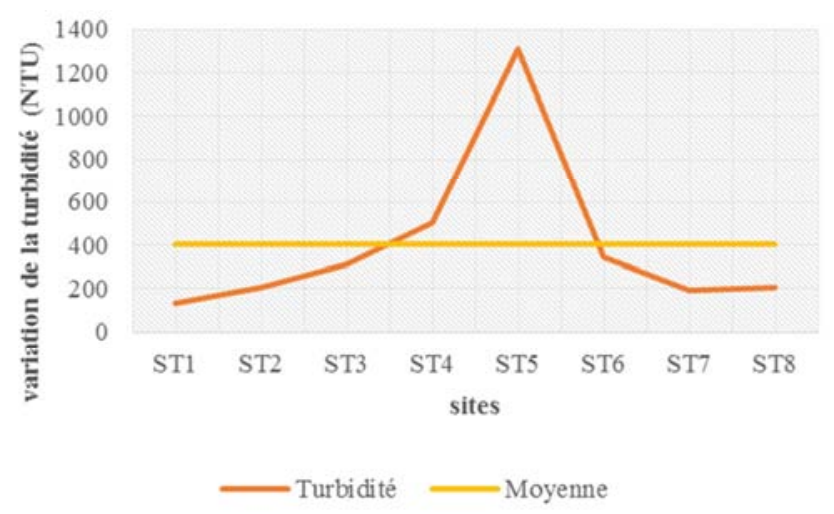

Figure 4. Spatial variation of water turbidity in the sampling area.

\subsubsection{Suspended Matter and Salinity of the Samples}

Figure 5 shows the variation of SS in the water at the sites sampled during the campaign. From the analysis of the graph, it appears that the shape of the curve of figure 5 is comparable to that of fig. 4. The contents of MES vary between 44.92 and $998.25 \mathrm{mg} / \mathrm{L}$ with an average of $276.81 \pm$ $116.70 \mathrm{mg} / \mathrm{L}$. The lowest value is observed at the ST1 site while the highest value is observed at the ST5 site. Our extreme (minimum and maximum) values obtained are higher than those obtained by [4] which is of zero $\mathrm{mg} / \mathrm{L}$ for the minima then respectively $65 \mathrm{mg} / \mathrm{L}$ and $198 \mathrm{mg} / \mathrm{L}$ for the maxima. From the superposition of the curves of Figures 4 and 5 , it is tempting to deduce that the turbidity of the water is caused exclusively by the suspended matter (SS). These SS are not exclusively from industry releases, but also from runoff that has been stranded in the Klou river.

Figure 6 shows the variation of the salinity in the water at the sites sampled during the campaign. From the analysis of the graph, it appears that the salinity varies between 0.02 and $0.21 \mathrm{ppt}$ with an average of $0.07 \pm 0.02 \mathrm{ppt}$. The lowest value is observed at the ST1 site while the highest value is observed at the ST5 site. The coefficient of variation (\% CV) of the salinity is 81.8 . This value of the coefficient of variation shows that the salinity values recorded are not homogeneous. The non-homogeneity in all the salinity data is caused by the values taken by this parameter at the ST4 and ST5 sites which are 4 to 7 times the water salinity at the ST3 site. The salinity of the river water just after the mouth of the plant effluent is higher than before the mouth. Therefore the effluents from the plant slightly disturb the physico-chemical balance of the Klou river without modifying it fundamentally because the salinity values return to normal at the ST8 site. Our extreme (minimum and maximum) values obtained are higher than those obtained by [4] which are of zero $\mathrm{mg} / \mathrm{L}$ for the minima then 10 and $20 \mathrm{ppb}$ respectively for the maxima. WHO recommends 1.5 . ppm in drinking water. Our values are in every respect well below this limit.

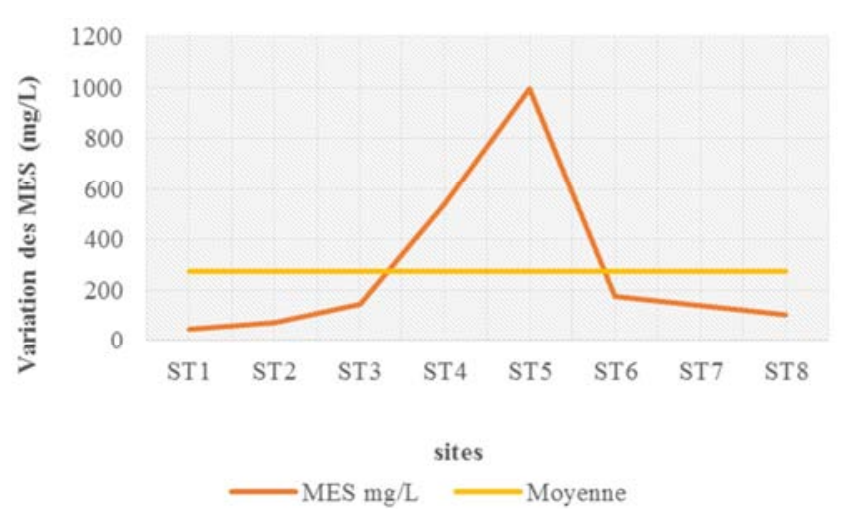

Figure 5. Variation of Suspended matter.

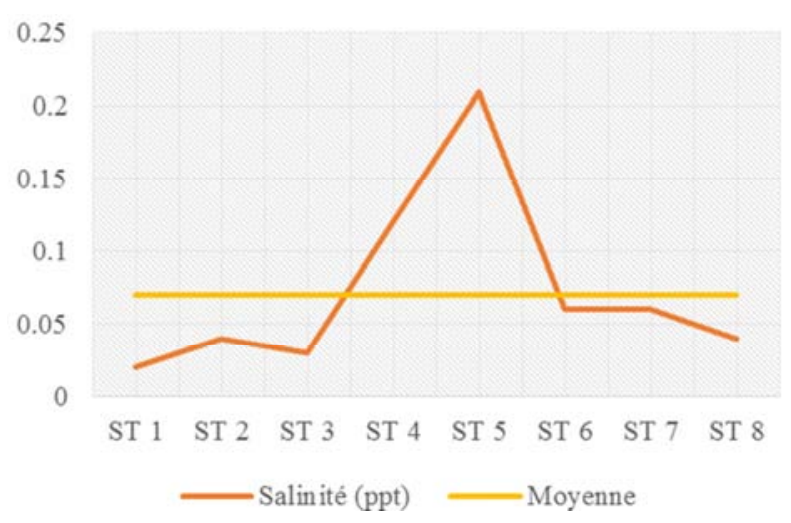

Figure 6. Spatial variation of water salinity.

\subsubsection{Spatio-temporal variation of nutriments}

\section{i. Total Iron}

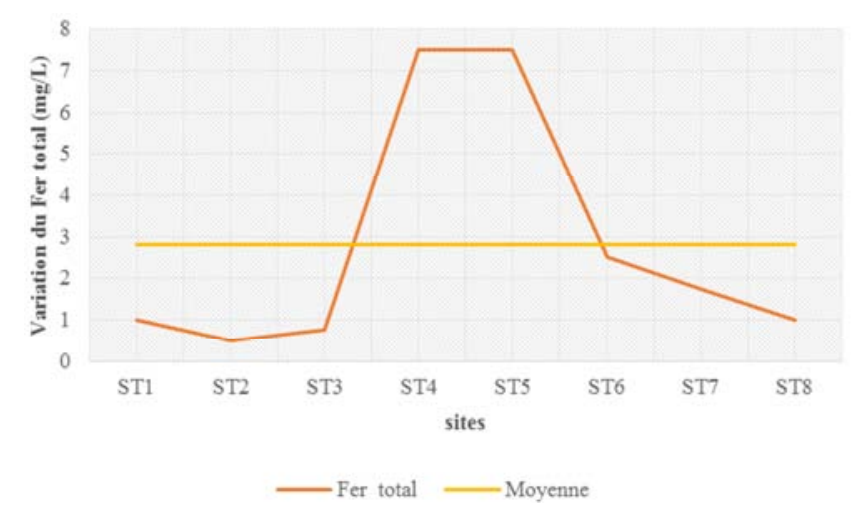

Figure 7. Spatial variation of Total Iron.

Figure 7 shows the variation of total iron in water at the sites sampled during the campaign. From the analysis of the 
graph, it appears that Total Iron varies between 0.5 and 7.5 $\mathrm{mg} / \mathrm{L}$ with an average of $2.81 \pm 1.05 \mathrm{mg} / \mathrm{L}$. The lowest value of total iron is observed at the ST2 site while the highest value is observed at the ST4 and ST5 sites. The coefficient of variation $(\% \mathrm{CV})$ of Total Iron is 105.25 , which allows us to state that the total Iron data are disparate. This disparity is due to the high total iron values recorded at the ST4 and ST5 sites. Our minimum value obtained is higher than those obtained by [4] which are respectively 0.09 and $0.04 \mathrm{mg} / \mathrm{L}$ and that of [14] on the dam of SONEB Okpara $(0.15 \mathrm{mg} / \mathrm{L})$. Our maximum value obtained is lower than those obtained by these same authors. Their values are respectively 10 and 9.12 $\mathrm{mg} / \mathrm{L}$ for both campaigns with averages of $2.2 \pm 3.11 \mathrm{mg} / \mathrm{L}$ and $2.36 \pm 2.88 \mathrm{mg} / \mathrm{L} \mathrm{[4]} \mathrm{and} 38 \mathrm{mg} / \mathrm{L}$ [14]. [11] laying down quality standards for wastewater in the Republic of Benin does not formally regulate total iron, but recommends that other inorganic pollutants not formally regulated should individually contain daily contents not exceeding $5.0 \mathrm{mg} / \mathrm{L}$. The maximum allowable value according to WHO guidelines for the quality of drinking water is $0.3 \mathrm{mg} / \mathrm{L}$. In our case, we are beyond this limit for waste water discharged by Logozohè food alcohol production plant. In fact a contamination of iron water is not a bad thing in itself. The human body needs it as a source of hemoglobin improvement. But high levels of contamination of iron water promotes a proliferation of microorganisms especially sulphate reducer using iron as an oxidant. These chemical processes lead to the reduction of sulphates $\mathrm{SO}_{4}{ }^{2-}$ into $\mathrm{H}_{2} \mathrm{~S}$ sulphide source of odor in anaerobic waters [15-16-4].

\section{ii. Total Manganese}

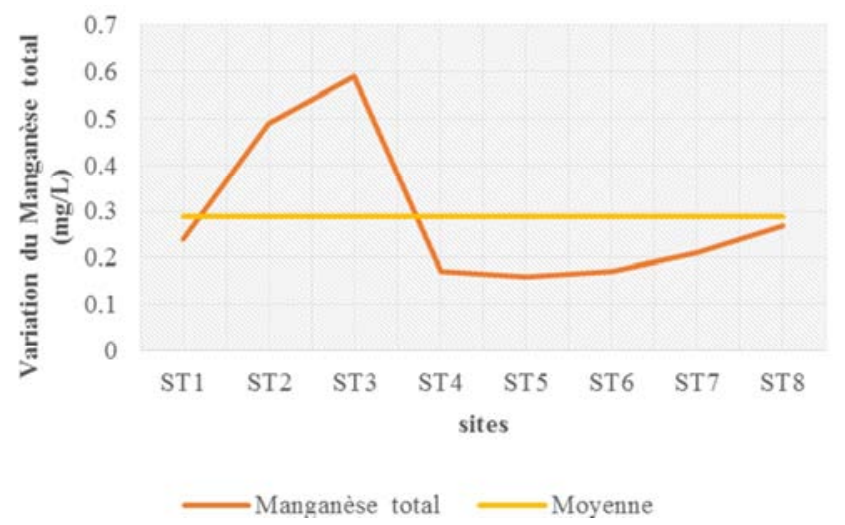

Figure 8. Spatial variation of total manganese.

Figure 8 shows the variation of total manganese in water at the sites sampled during the campaign. From the analysis of the graph, it appears that the total manganese varies between 0.16 and $0.59 \mathrm{mg} / \mathrm{L}$ with an average of $0.29 \pm 0.06 \mathrm{mg} / \mathrm{L}$. The lowest value is observed at the ST5 site while the highest value is observed at the ST3 site. Our values obtained are lower than those obtained by [14] at the Okpara dam with extreme values (minimum maximum) respectively 0.07 to $5.5 \mathrm{mg} / \mathrm{L}$. The total iron $(0.75 \mathrm{mg} / \mathrm{L})$ and total manganese $(0.59 \mathrm{mg} / \mathrm{L})$ values at the ST3 site show that these values stand and reflect the telluric origin followed by a phenomenon of accumulation of these parameters at the dam level [17-21].

\section{iii. Chloride Ion Content}

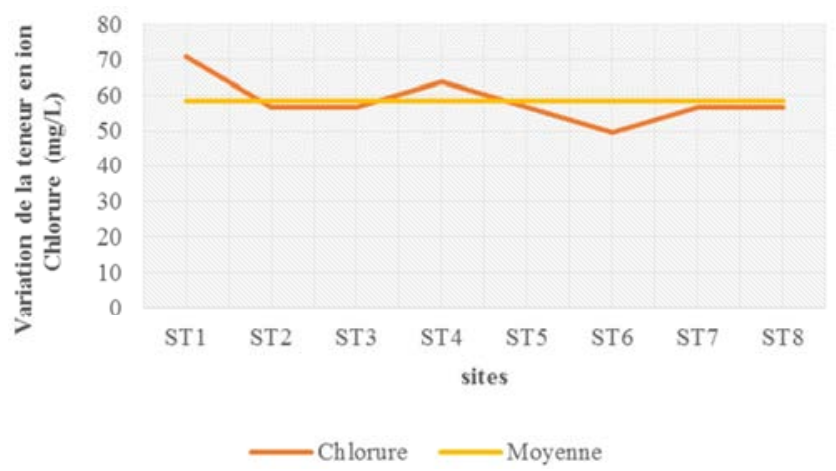

Figure 9. Spatial variation in chloride ion.

Figure 9 shows the variation of chloride ion in water at sites sampled during the campaign. From the analysis of the graph, it appears that the chloride ion concentrations vary between 49.7 and $71 \mathrm{mg} / \mathrm{L}$ with an average of $58.575 \pm 2.23$ $\mathrm{mg} / \mathrm{L}$. The lowest value is observed at the ST6 site while the highest value is observed at the ST1 site. Also, the coefficient of variation $(\% \mathrm{CV})$ of chloride ions at the sites sampled is 10.74. This value shows that the degree of homogeneity of the recorded values is acceptable. This homogeneity reflects a lack of unusual contribution of chloride ion to the receiving medium. Our minimum value obtained is higher than those obtained by [4] which are respectively 24.85 and $14.2 \mathrm{mg} / \mathrm{L}$. Our maximum value obtained is lower than those obtained by these same authors who are respectively 142 and $149.1 \mathrm{mg} / \mathrm{L}$ for both campaigns. The drinking water quality guidelines require a maximum value of $250 \mathrm{mg} / \mathrm{L}$ [11]. All values obtained are below this limit.

\subsubsection{Hardness of Water and Alkalinity of Samples}

Figure 10 shows the spatial variations in water hardness. From the analysis of the curves, it appears that the calcium hardness varies between 1.78 and $5.35^{\circ} \mathrm{f}$ with an average of $2.45 \pm 0.47^{\circ}$. The lowest value is observed at sites ST1, ST2, ST3, ST6, ST7 and ST8 while the highest value is observed at the level of the main effluent of the plant, that is to say at the ST4 site level. The magnesium hardness varies from "not determined" (ND) to $36.05^{\circ} \mathrm{F}$ with an average of $8.11 \pm$ $4.18^{\circ}$ f. The lowest value is observed at the ST1 site while the highest value is observed at the ST3 or Logozohè dam site. Calcium and magnesium hardnesses are not regulated by the standards of rejections in Benin. On the other hand, the Benin standard on the quality of drinking water sets the limit of calcium and magnesium hardness respectively at $25^{\circ} \mathrm{F}(100$ $\mathrm{mg} / \mathrm{L})$ and $23.83^{\circ} \mathrm{F}(50 \mathrm{mg} / \mathrm{L})$. All levels of calcium hardness recorded are well below this threshold. On the other hand, at the level of the magnesium hardness, the value recorded at the ST3 site exceeds the threshold. The temporary hardness or bicarbonate hardness varies between 4 and $8^{\circ} \mathrm{f}$ with an average of $6.25 \pm 0.6^{\circ} \mathrm{f}$. The lowest value is observed at sites ST1 and ST4 while the highest value is observed at sites ST5, 
ST6 and ST7. The total hardness (TH) ranges from 1.78 to $37.83^{\circ} \mathrm{F}$ with an average of $10.56 \pm 4.22^{\circ} \mathrm{f}$. The lowest value is observed at the ST1 site while the highest value is observed at the ST3 site as the magnesium hardness. The Beninese standard on the quality of drinking water requires a limit of $200 \mathrm{mg} / \mathrm{L}$ for the hardness is $20^{\circ} \mathrm{f}$. The ST3 site alone has a hardness above this threshold. This jump in value of the magnesic and total hardness at the ST3 site would be related to a phenomenon of accumulation.

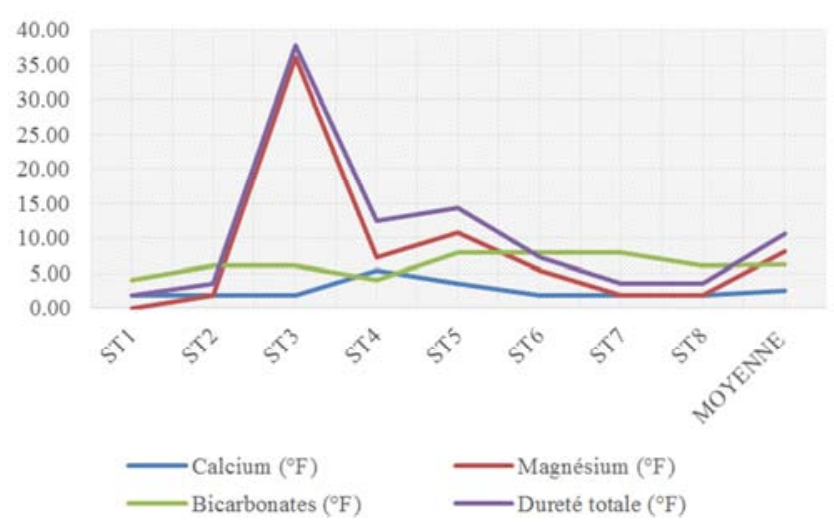

Figure 10. Spatial variation in water hardness.

Figure 11 shows the variation of alkalinity in water at the sites sampled during the campaign. From the analysis of the graph, it appears that the alkalinity varies between 4 and $8^{\circ} \mathrm{f}$ with an average of $6.25 \pm 0.6^{\circ} \mathrm{f}$. The lowest value is observed at sites ST1 and ST4 while the highest value is observed at sites ST5, ST6 and ST7. Our extreme (minimum and maximum) values obtained are higher than those obtained by [4] which are respectively 1.1 and $0.4^{\circ} \mathrm{f}$ for the minima and then 8 and $2^{\circ}$ f respectively for the maxima. For a $\mathrm{pH}$ ranging between 5.32 and 7.52, the alkalinity is exclusively related to the bicarbonate ions.

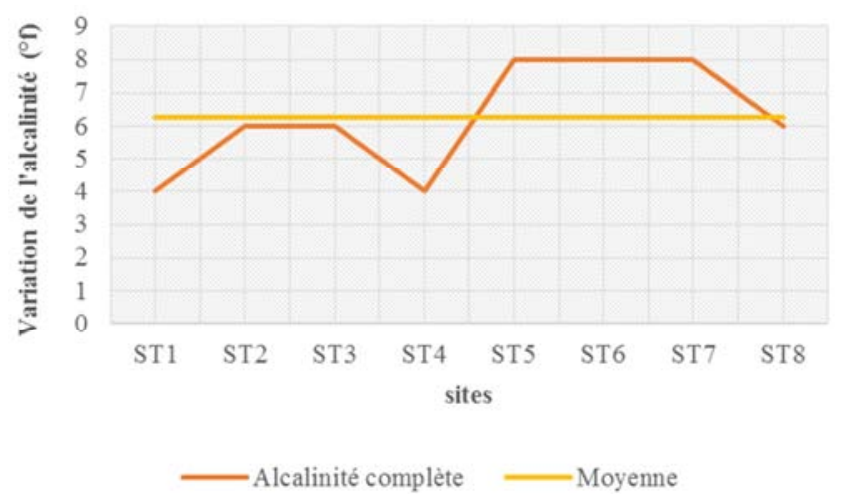

Figure 11. Spatial variation of alkalinity of water in the sampling area.

\subsubsection{Nitrogen Pollution and Orthophosphate}

Table 3 presents the variations in nitrogen pollution in wastewater from the agri-food industry and the klou river.

Table 3. Variation of nitrogen pollution in the study area.

\begin{tabular}{|c|c|c|c|c|c|c|c|c|c|c|}
\hline Site Settings & ST1 & ST2 & ST3 & ST4 & ST5 & ST6 & ST7 & ST8 & Average & Ecart-type \\
\hline Nitrates $\mathrm{N}^{-\mathrm{NO}_{3}}{ }^{-}(\mathrm{mg} / \mathrm{L})$ & $<1$ & 6 & $<1$ & 2 & 2 & $<1$ & $<1$ & $<1$ & 1,25 & 0,81 \\
\hline Nitrites $\mathrm{N}-\mathrm{NO}_{2}^{-}(\mathrm{mg} / \mathrm{L})$ & $<0.046$ & $<0.046$ & 0.04 & $<0.046$ & $<0.046$ & $<0.046$ & $<0.046$ & $<0.046$ & ND & ND \\
\hline Ammonium N-NH${ }_{4}^{+}(\mathrm{mg} / \mathrm{L})$ & 0,6 & 1 & 0,8 & 3,5 & 3,7 & 1,9 & 0,4 & 1,2 & 1,6375 & 0,46 \\
\hline NTK $(\mathrm{mg} / \mathrm{L})$ & 2,8 & 1 & 3 & 21,2 & 34,1 & 2,8 & 0,7 & 5,6 & 7,51 & 4,6 \\
\hline
\end{tabular}

$<$ : sign of inferiority; ND: Not Determined

Table 3 presents the variation of nitrogen pollution in the study area. From the analysis of the table data, it appears that the oxidized form of the nitrogen pollution (NO2- and NO3-) is negligible as a whole, except at the ST2, ST4 and ST5 sites for the nitrate ions where the measured values are respectively $6 \mathrm{mg} / \mathrm{L}$ and $2 \mathrm{mg} / \mathrm{L}$. For the nitrite ion outside the ST3 site where the measured value is $0.04 \mathrm{mg} / \mathrm{L}$, all other sites have nitrite ion values of less than $0.04 \mathrm{mg} / \mathrm{L}$. The Ammonium ion varies between 0.4 and $3.7 \mathrm{mg} / \mathrm{L}$ with an average of $1.64 \pm 0.46 \mathrm{mg} / \mathrm{L}$. The lowest value is observed at the ST7 site while the highest values are observed at the ST4 and ST5 sites. The coefficient of variation (\% CV) of the ammonium ion contents is $79 \%$, showing that the contents of this parameter change to sawtooth. The Beninese standard for waste water did not regulate ammonium ions. The variation of NTK in water at the sites sampled during the campaign ranged from 0.1 to $34.1 \mathrm{mg} / \mathrm{L}$ with an average of $7.51 \pm 4.6$ $\mathrm{mg} / \mathrm{L}$. The lowest value is observed at the ST2 sites while the high values are observed at the ST4 and ST5 sites. The Beninese standard for wastewater recommends $200 \mathrm{mg} / \mathrm{L}$. Our values are well below this limit. These low values of the
NTK result from the fact that the current campaign was carried out at a time when the plant is idle and secondly that the majority of the pollution discharged was leached by rainwater. The measurement of NTK represents the sum of $\mathrm{NH} 4+$ contents and organic nitrogen. From the data in Table 3 we find that the low nitrogen pollution is essentially organic. On the other hand, if $\mathrm{NH}_{4}^{+}$is not directly toxic to aquatic fauna, its conjugate base $\mathrm{NH} 3$ is very toxic for ichthyenne fauna. But our $\mathrm{pH}$ values ranging between 5.32 and 7.52 do not allow to glimpse a significant presence of $\mathrm{NH} 3$ in the receiving medium.

Figure 12 shows the variation of orthophosphate in water at the sites sampled during the campaign. From the analysis of the graph, it appears that the orthophosphate varies between 0 and $2.7 \mathrm{mg} / \mathrm{L}$ of $\mathrm{P}$ with an average of $0.71 \pm 0.43$ $\mathrm{mg} / \mathrm{L}$. The lowest value is observed at the ST3 sites while the higher values are observed at the ST4 and ST5 sites. These values are much higher than those obtained by [12] which are very close to zero. The threshold for phosphorus release is 2 $\mathrm{mg} / \mathrm{L}$ for sensitive media [11]. The total phosphorus input of effluents from the mill to the watercourse exceeds this limit. 
This state of affairs exposes the receiving environment to eutrophication and, in the long term, to the death of the stream downstream from the point of discharge of the plant if no action is taken.

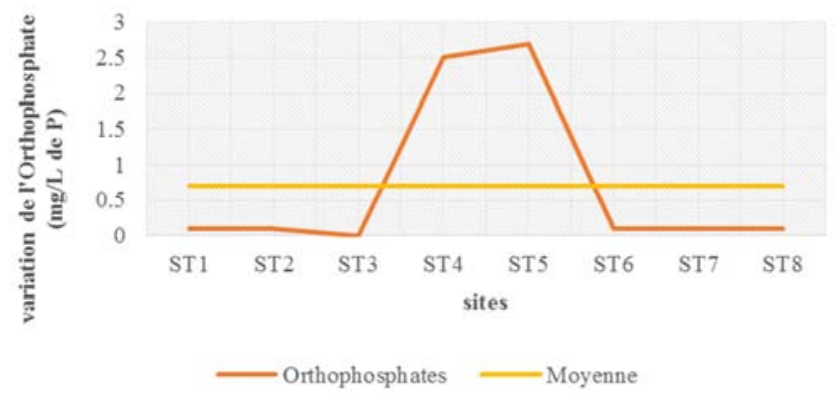

Figure 12. Spatial variation of Orthophosphate in samples.

\subsubsection{Variation of the $N / P$ ratio in the samples}

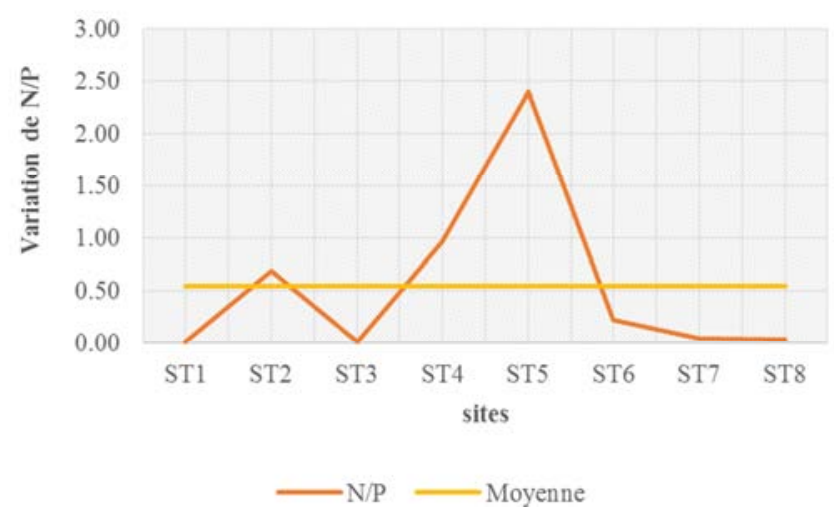

Figure 13. Spatial variation of the N/P ratio in the samples.

Figure 13 shows the variation of the N/P ratio in the water at the sites sampled during the campaign. From the analysis of the graph, it appears that the ratio N/P varies between 0.01 to 2.40 with an average of $0.55 \pm 0.3$. The lowest value is observed at the ST1 site while the highest value is observed at the ST5 sites. All of these N/P ratios are below 7.2, indicating that nitrogen is the limiting factor for eutrophication [18]. This limiting nitrogen is very available. Depending on the organisms, it can be captured directly in the air and/or come from run-off water having leached agricultural areas chemically amended by agricultural fertilizers.

\subsubsection{Biochemical Oxygen Demand (BOD) and Chemical Oxygen Demand (COD) in Water Samples}

Figure 14 shows the variation of $\mathrm{BOD}_{5}$ in the water at the sites sampled during the campaign. From the analysis of the graph, it appears that the $\mathrm{BOD}_{5}$ varies in sawtooth from the ST1 site to the ST8 site. The values for $\mathrm{BOD}_{5}$ range from 0 to $102 \mathrm{mg} \mathrm{O}_{2} / \mathrm{L}$ with an average of $33.38 \pm 13.54 \mathrm{mg} \mathrm{O}_{2} / \mathrm{L}$. The lowest value is observed at the ST4, ST6 and ST8 sites while the highest value is observed at the ST5 site. Our minimum value obtained is consistent with those obtained by [4] which is $0 \mathrm{mg} \mathrm{O} / 2$ L. Our maximum value obtained is higher than those obtained by these same authors who are

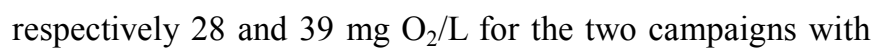
average values of $12.846 \mathrm{mg}$ and $19.692 \mathrm{mg}$ of $\mathrm{O}_{2} / \mathrm{L}$. On the other hand, our minimum value is lower than that obtained by [20] which is $10 \mathrm{mg} \mathrm{O}_{2} / \mathrm{L}$ for a maximum value of $29 \mathrm{mg}$ $\mathrm{O}_{2} / \mathrm{L}$. $\mathrm{BOD}_{5}$ expresses the amount of oxygen required for degradation of biodegradable organic matter in one liter of water by microorganisms at $20^{\circ} \mathrm{C}$. It is a way of assessing the biodegradable organic matter content of a receiving medium through the cost of dissolved oxygen to pay for eliminating this pollution. The Beninese industrial wastewater discharge standard sets a limit of $0.11 \mathrm{~kg}$ of $\mathrm{BOD} / \mathrm{hL}$ of products manufactured for the agrifood industries or just $100 \mathrm{mg}$ of $\mathrm{BOD} / \mathrm{L}$ of wastewater discharged. This value is reached only at the ST5 site probably due to the accumulation phenomenon. The ST4, ST6 and ST8 sites where the measured value of $\mathrm{BOD}_{5}$ is zero are located on the penetration side of the main effluent from the mill into the watercourse. It is as if in each of these points, it is always the $\mathrm{BOD}_{5}$ of the main effluent that is measured. This can be explained by the fact that the discharged effluent does not mix rapidly with the waters of the watercourse due to the difference in density (wastewater $\approx$ river water $\approx$ ) and seems to be pushed along the river.

Figure 15 shows the variation of COD in water at the sites sampled during the campaign. From the analysis of the graph, it appears that the COD varies between 49.06 and $4612.11 \mathrm{mg} \mathrm{O}_{2} / \mathrm{L}$ with an average of $1150.04 \pm 577.43 \mathrm{mg}$ $\mathrm{O}_{2} / \mathrm{L}$. The lowest value is observed at the ST1 site while the highest value is observed at the ST5 site. Our minimum value obtained is consistent with those obtained by [4] which is 0 $\mathrm{mg} \mathrm{O}_{2} / \mathrm{L}$. Our maximum value obtained is greater than those obtained by these same authors who are respectively 189 and $245 \mathrm{mg} \mathrm{O}_{2} / \mathrm{L}$ for the two campaigns with average values of $12.846 \mathrm{mg}$ and $19.692 \mathrm{mg}$ of $\mathrm{O}_{2} / \mathrm{L}$. This shows that there is a shortage of Oxygen in the river and raises many questions about the future of this river if nothing is done when we know that Oxygen is essential for life [20]. The Beninese standard did not specifically regulate the COD at the level of the rejects of the agro-food industries. On the other hand, at the level of other industries, the threshold of COD varies according to the type of industry. The threshold not to be exceeded is $30 \mathrm{~kg}$ of COD/tonne of finished product. The standard requires a maximum daily release of COD not exceeding $300 \mathrm{mg} / \mathrm{L}$. This limit is exceeded at the ST4, ST5, ST6 and ST8 sites. Recall that in these points the $\mathrm{BOD}_{5}$ is zero except at the site ST5. This observation suggests that the effluent discharged by the plant into the watercourse is mainly loaded with organic matter refractory to biodegradation. This type of pollution is very damaging to the receiving environment, which manifests itself in the loss of the river's biodiversity and the emission of foul odors that is harmful to local residents. 


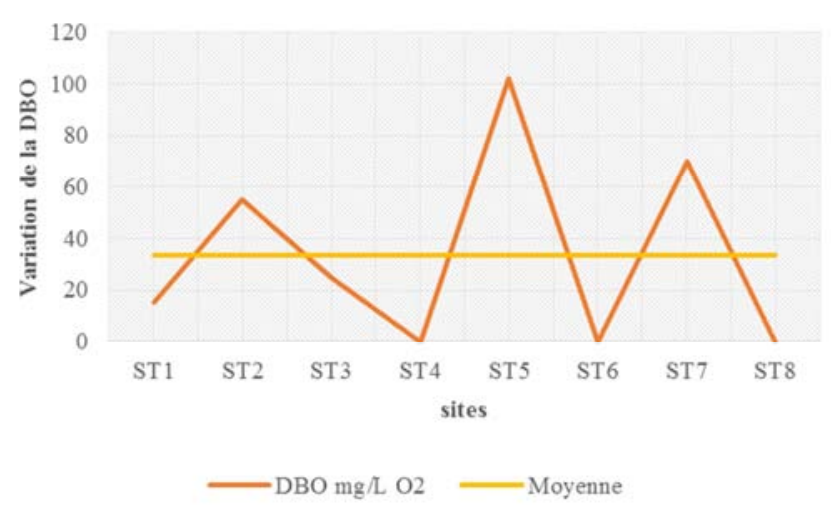

Figure 14. Spatial variation of $B O D$ in water samples.

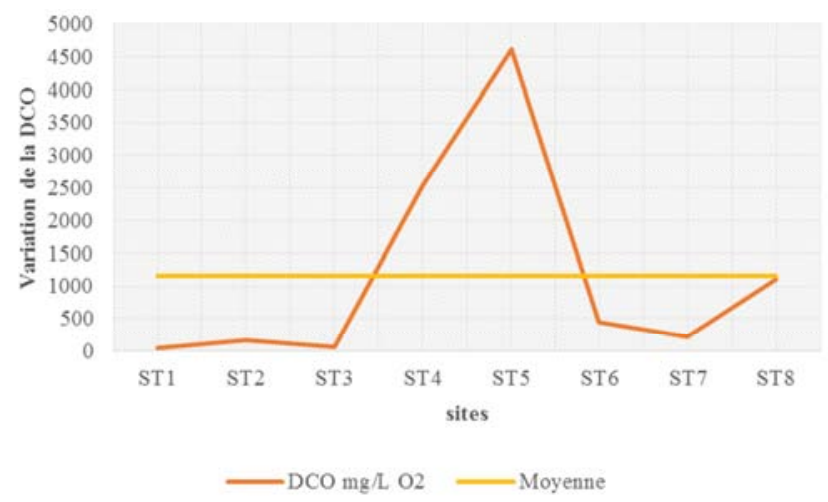

Figure 15. Change in $C O D$ in the water of the sampling area.

\subsubsection{Variation in $\mathrm{BOD} / \mathrm{COD}$ Ratio in Samples}

Figure 16 shows the variation of the BOD/COD ratio in the water at the sites sampled during the campaign. From the analysis of the graph, it appears that the BOD/COD ratio varies between 0 and 0.38 with an average of $0.17 \pm 0.06$. The lowest value is observed at the ST4, ST5 and ST6 sites while the highest values are observed at the ST1, ST2, ST3 and ST7 sites. According to [4], the $\mathrm{BOD}_{5} / \mathrm{COD}$ ratio gives a first estimate of the biodegradability of the organic matter of an effluent at the intervals below:

(1) $\mathrm{BOD}_{5} / \mathrm{COD}>0.5$ : the effluent is easily biodegradable.

(2) $0.33<\mathrm{BOD}_{5} / \mathrm{COD}<0.5$ the effluent is biodegradable with selected strains.

(3) $0 \leq \mathrm{BOD}_{5} / \mathrm{COD}<0.33$ the effluent is not biodegradable.

Virtually all the water in the Klou river is not biodegradable except at the ST2 and ST3 sites where it is difficult to biodegrade with selected bacterial strains. This state of affairs may be justified by the fact that the Klou river is in a highly agricultural zone where the use of synthetic pesticides is widespread, the runoff having leached from freshly sprayed agricultural areas drained pesticide residues in the stream making it refractory to biodegradation. Also, this non-biodegradability of the water has been reinforced by the effluents of the plant. Thus, depending on the biological treatment sought and the bacterial populations to be favored, the following nutritional ratios should also be respected:

(1) $10<\mathrm{COD} / \mathrm{N}<60$, to promote denitrification (conversion of nitrogen in the form of nitrates to nitrogen gas);

(2) $30<\mathrm{COD} / \mathrm{P}<300$, to promote the dephosphatation (overaccumulation of phosphorus by bacteria).

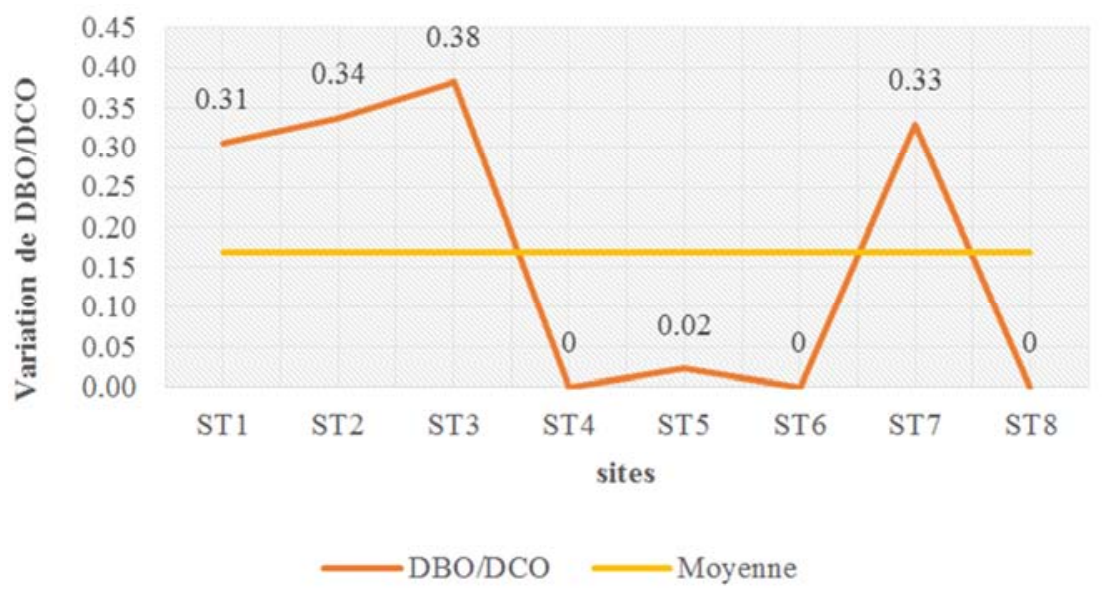

Figure 16. Spatial variation of the $B O D / C O D$ ratio in the samples.

\subsection{Analysis of Sampling Sites}

The different links between the pollution parameters monitored and the sampling sites are given in Tables 4 to 8 and Figures 17 and 18 .

Table 4. Eigenvalues.

\begin{tabular}{llllllllll}
\hline Eigenvalue & $\mathbf{1 2 . 6 1 1}$ & $\mathbf{3 . 7 1 1}$ & $\mathbf{2 . 7 1 7}$ & $\mathbf{1 . 7 5 8}$ & $\mathbf{0 . 6 1 4}$ & $\mathbf{0 . 4 8 2}$ & $\mathbf{0 . 1 0 8}$ & $\mathbf{0}$ & $\mathbf{0}$ \\
\hline Proportion & 0.573 & 0.169 & 0.123 & 0.08 & 0.028 & 0.022 & 0.005 & 0 \\
Cumulative & 0.573 & 0.742 & 0.865 & 0.945 & 0.973 & 0.995 & 1 & 1 \\
\hline
\end{tabular}


The analysis of vectors and eigenvalues shows that the first three main components account for more than $86.5 \%$ of the information contained in the initial variables. We can therefore use the first three components to interpret the relationships between the input variables since the share of information that these (03) components group together is greater than $50 \%$ (Table 4 ).

Table 5. Correlation Between Variables.

\begin{tabular}{llll}
\hline Variables & PC1 & PC2 & PC3 \\
\hline Turbidity & 0.24 & -0.251 & -0.03 \\
Temperature & 0.275 & 0.05 & -0.084 \\
Potential Hydrogen & -0.139 & -0.344 & -0.026 \\
Electrical conductivity & 0.275 & 0.003 & -0.064 \\
Complete alkalinity & 0.015 & -0.396 & -32 \\
Chloride & 0.016 & 0.333 & -0.82 \\
Calcium & 0.243 & 0.153 & -0.451 \\
Magnesium & -0.011 & -0.229 & -0.465 \\
Total hardness & 0.017 & -0.21 & 0.041 \\
Dissolved oxygen & -0.273 & -0.079 & -0.019 \\
Ammonium & 0.272 & -0.01 & -0.039 \\
Oxydability & 0.278 & -0.01 & -0.344 \\
Total iron & 0.278 & 0.016 & 0.009 \\
Total manganese & -0.175 & -0.183 & 0.005 \\
BOD & 0.072 & -0.383 & -0.048 \\
COD & 0.267 & -0.113 & -0.058 \\
MES & 0.265 & -0.162 & -0.269 \\
NTK & 0.273 & -0.096 & -0.016 \\
Pt & 0.109 & 0.374 & -0.288 \\
N/P & 0.258 & -0.178 & -0.28 \\
DBO/DCO & -0.197 & -0.107 & -0.104 \\
DBO/(DBO+DCO) & -0.196 & & \\
\hline
\end{tabular}

Summarizing the different correlations in Table 6 we note that:

Table 6. Main Components and Types of Correlations with Starting Variables.

\begin{tabular}{llll}
\hline Sign & PC1 & PC2 & PC3 \\
\hline- & Dissolved Oxygen & Turbidity, Potential hydrogen, & $\begin{array}{l}\text { DBO/DCO, Magnesium, total } \\
\text { hardness, total manganese }\end{array}$ \\
& $\begin{array}{l}\text { N/P, DCO, MES, NTK, Ammonium, oxydability, total iron, Calcium, } \\
\text { electrical conductivity, Temperature }\end{array}$ & Chloride, Pt & Complet alkalinity \\
\hline
\end{tabular}

(1) On the first axis (principal component PC1), the MES are to a lesser extent positively correlated with the ammonium ions, the COD, and NTK appearing as well as the majority of the MES are organic that mineral corroborating the thesis according to which the nonbiodegradability of The Klou river is caused by runoff from agricultural areas treated with refractory agricultural inputs such as organochlorine pesticides. On this first component, there is also a negative correlation between dissolved oxygen and SS, oxidability, COD, NTK, ammonium ions and total iron. This state of affairs can be explained by the fact that the main causes of the low dissolved oxygen content of Klou river water are the presence of iron and organic matter in the water column.

(2) On the second axis (principal component PC2), the turbidity, the $\mathrm{BOD}$, the $\mathrm{pH}$ and the total alkalinity on the one hand and on the other hand the $\mathrm{Pt}$ are negatively correlated. In other words, an increase in the Pt content promotes a microbial proliferation that accelerates the decomposition of the biodegradable organic matter into $\mathrm{CO}_{2}$ and $\mathrm{H}_{2} \mathrm{O}$ according to the equation: $\left\{\mathrm{CH}_{2} \mathrm{O}\right\}+\mathrm{O}_{2} \leftrightarrow \mathrm{CO}_{2}+\mathrm{H}_{2} \mathrm{O}$. The production of $\mathrm{CO} 2$ influences the $\mathrm{pH}$ and the production of bicarbonate (HCO3-) according to the equation: $\mathrm{CO}_{2}+$ $2 \mathrm{H}_{2} \mathrm{O} \leftrightarrow \mathrm{H}_{3} \mathrm{O}^{+}+\mathrm{HCO}_{3}^{-}$. On the third axis (component $\mathrm{PC} 3$ ), magnesium and total hardness are positively correlated. This observation shows that the total hardness is mainly magnesium. The negative correlation between the BOD/COD ratio and the total alkalinity is still justified by the biodegradation of the organic matter in favor of the production of bicarbonate.

Tables 7 and 8 show the sets of points that have similarities and the correlations between monitored parameters and sampling points.

Table 7. Main Components and Types of Site Correlations.

\begin{tabular}{llll}
\hline Sign & PC1 & PC2 & PC3 \\
\hline- & & Site 1, site 3, site 5 & Site 8 \\
+ & Site 2, site 4, site 7 & Site 6 & \\
\hline
\end{tabular}




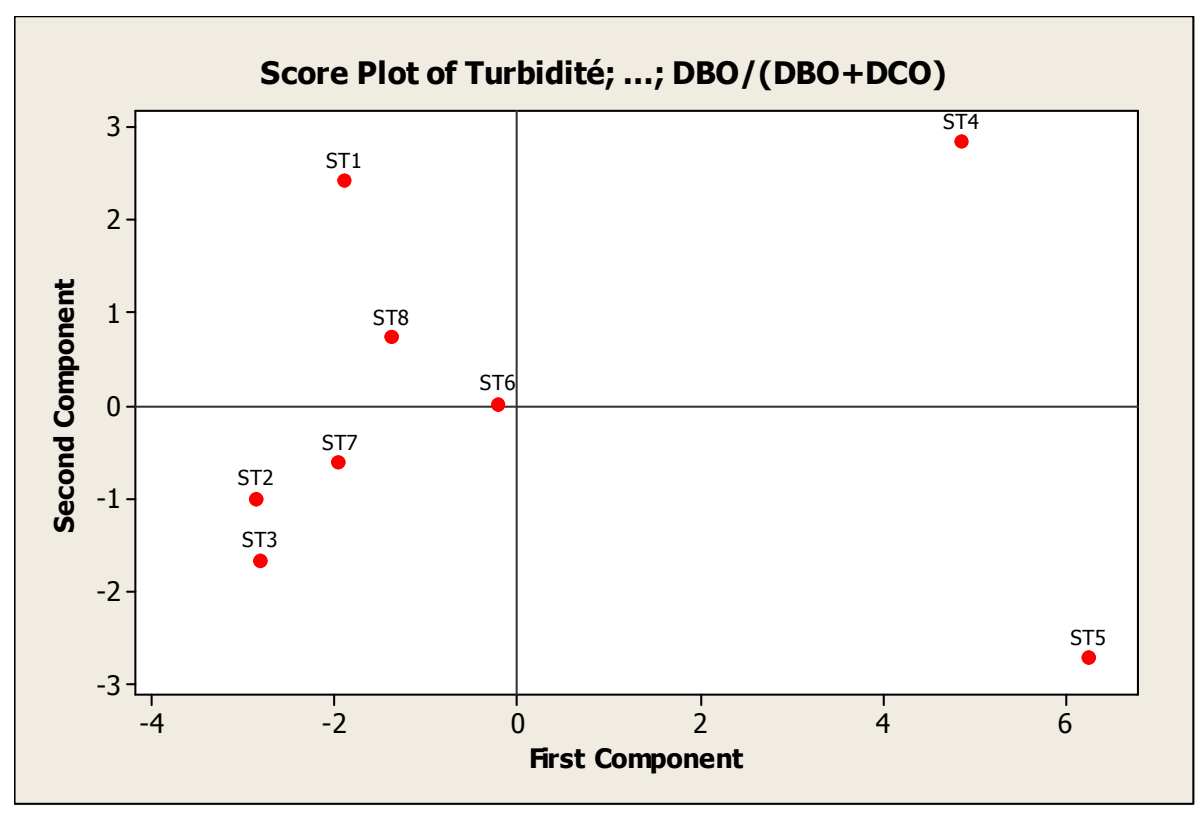

Figure 17. Score plot.

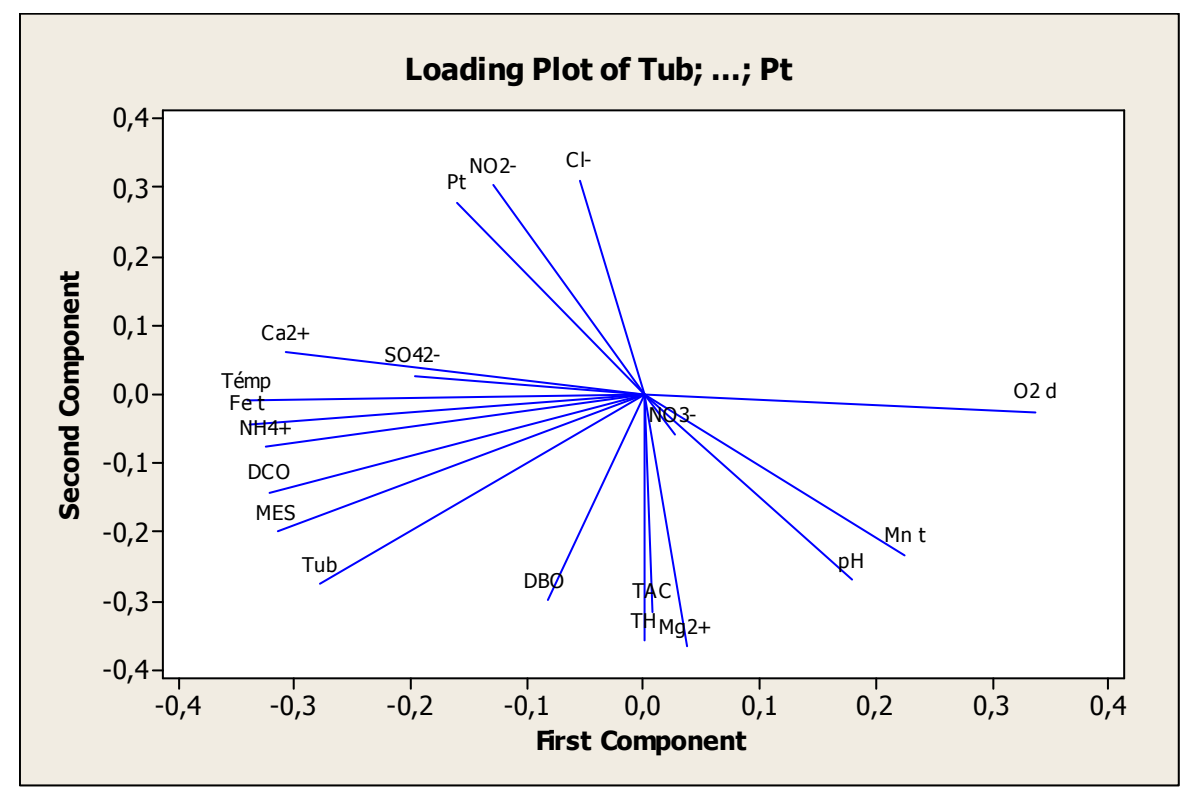

Figure 18. Loading plot.

Table 8. Analysis of relationships between pollutants and sites.

\begin{tabular}{llll}
\hline Signe & PC1 & PC2 & PC3 \\
\hline- & Dissolved Oxygen & $\begin{array}{l}\text { Turbidity, Potential hydrogen, complete } \\
\text { alkalinity, DBO, Site 1, Site 3, site 5 }\end{array}$ & $\begin{array}{l}\text { DBO/ (DCO+DCO), DBO/DCO, Site 8, } \\
\text { Magnesium, total hardness, total manganese }\end{array}$ \\
& $\begin{array}{l}\text { N/P, DCO, MES, NTK, Ammonium, oxydability, } \\
\text { total iron, Calcium, electrical conductivity, } \\
\text { Temperature, Site 2, site 4, site 7 }\end{array}$ & Site 6, Chloride, Pt & Complete alkalinity \\
\hline
\end{tabular}

It appears that :

(1) the sites 2, 4 and 7 have, to a small extent, a high electrical conductivity associated with a high temperature, a high ammonium content, a high level of calcium, a large amount of total iron, a high degree of oxidation, a high ratio of High N/P, a large COD, MES,
NTK but not associated to a small extent with a large amount of dissolved oxygen. This finding simply shows that the availability of Organic Matter (OM) in the water column is negatively correlated with the availability of dissolved oxygen. In other words, at sites 2, 4 and 7 the biodegradation of the organic 
material is very active and generates other electrolytes such as $\mathrm{NH}_{4}^{+}$ions and the source heat of high temperatures recorded ;

(2) sites 1, 3 and 5 have a high hydrogen potential which is associated with a high total alkalinity, a high biochemical oxygen demand (BOD) and, to a lesser extent, a high turbidity while the site 6 has a high rate of chloride associated with a high level of total phosphorus (Pt);

(3) the site 8 has a high magnesium content which is associated with a high total hardness and a high total manganese content and, to a lesser extent, a high $\mathrm{BOD} / \mathrm{COD}$ ratio, but is not associated with a high total alkalinity.

\section{Conclusion}

At the end of our study, the analytical methods made it possible to characterize the liquid effluents emitted by the alcohol factory of Logozohè and to evaluate the levels of contamination of the Klou river through the determination of the physicochemical parameters of water quality. From our results, the $\mathrm{pH}$, turbidity, $\mathrm{SS}$, and $\mathrm{COD}$ of water at the main effluent and Klou river do not meet the drinking water and wastewater quality standards in the Republic of Benin. The organic pollution of the effluent discharged by the plant into the watercourse is mainly loaded with organic matter refractory to biodegradation. This type of pollution is very damaging to the receiving environment, which manifests itself in the loss of the river's biodiversity and the emission of foul odors that is harmful to local residents. Similarly, the calculation of the $\mathrm{BOD}_{5} / \mathrm{COD}$ ratio has also revealed that almost all the water in the Klou river is not biodegradable except at the ST2 and ST3 sites, where it is difficult to biodegrade with selected bacterial strains. This nonbiodegradability of water has been reinforced by plant effluents that do not undergo adequate treatment.

\section{References}

[1] Dieme, D., 2011. Caratérisation physicochimique et étude des effets toxiques sur des cellules pulmonaires BEAS-2B des polluants particulaires de la ville de Dakar (Sénégal). Thèse de doctorat de l’Université du Littoral-Côte d'Opale. 182p.

[2] Senécal P. 2010. Histoire de l'interprétation néolithique. Evolution des théories, modèles et hypothèses. Mémoire ès sciences de Maîtrise en anthropologie de l'Université de Montréal. 197 p.

[3] Houngbo, S. A. P., Gbaguidi, A. N. M., Josse, R. G., Zannou, A., Yehouenou B. B., Toklo R. M., Fatombi J. and DossouYovo, P. 2018. Study of the chemical and bacteriological quality of water resources in Hozin, district of the commune of Dangbo in Benin. International Journal of Chemical Studies, 6 (1), 146-160.

[4] Lalayè, L., 2013. Suivi de la pollution chimique dans les eaux $\mathrm{du}$ chenal de Cotonou. Mémoire de Master (Msc) du Centre Interfacultaire de Formation et de Recherche en Environnement pour le Développement Durable (CIFRED).
Option Science Environnementale et Développement Durable. Spécialité Environnement-Santé et Développement Durable. Université d'Abomey-Calavi. 104 p.

[5] Wissen A. and Mohamed K. 2016. Evaluation de la qualité physico-chimique et bactériologique des eaux de puits de la region d'El-Harrouch (N. E-Algérie). J. Mater. Environ. Sci. 7(4): 1288-1297.

[6] Youssao A. K. A, Gbaguidi A. N. M., Baltrons O., Seby F., Monperus M., Soclo H. H., Donard O. 2018. Quantitative Analysis of Mineral Elements in Commercial Pineapple Juices by Inductively Coupled Plasma Mass Spectrometry (ICP-MS). International Journal of Food Science and Biotechnology. 3(2): 60-69. doi: 10.11648/j.ijfsb.20180302.14

[7] Gbaguidi, A. N. M, Dovonon L. F., Youssao AK. A, Saizonou K. M., Djibril R., Mohamed Y. I., Soclo H. H. and Fayomi B. 2014. Search of Organochlorine Pesticide Residues (Pocs) in Bodies of Water in CottonGrowing Area of Benin by GCECD. Pak. J. Chem. 4(2): 49-61.

[8] Sintondji, O. L., Awoye, H. R., and Agbossou, E., 2008. Modélisation du bilan hydrologique du bassin versant du Klou au Centre du Bénin: Contribution à la gestion durable des ressources en eau. Bulletin de la Recherche Agronomique du Bénin, (35-48), 81.

[9] Besancenot, J. and Boko, M., 2016. Climats et communautés rurales du Bénin: rythmes climatiques et rythmes de développement. Annale de géographie $\mathrm{N}^{\circ}$ 545. 117-120.

[10] Capo-chichi, Y. and Guidibi, E., 2006. Monographie de la Commune de Savalou. 82p.

[11] Rodier, J., Legube, B., and Merlet, N., 2009. analyse de l'eau Rodier. 9ème édition. $1579 \mathrm{p}$.

[12] Decret $N^{\circ} 2001-109$ du 4 Avril 2001 fixant les normes de qualité des eaux résiduaires en République du Bénin.

[13] Zinsou, L. H., Attingli, H. A., Gnohossou, P., and Adandedjan, D., 2016. Caractéristiques physico-chimiques et pollution de l'eau du delta de l'Ouéme au Benin. Journal of Applied Biosciences, (March 2015), 9163-9173.

[14] Anonyme, 2011. Guidelines for Drinking-water Quality. 564p.

[15] Zogo, D., Soclo, H. H., Bawa, M., and Gbaguidi, M., 2006. Distribution des résidus de Fer et de Manganèse le long de la colonne d'une retenue d'eau en cours d'eutrophisation: cas du barrage de l'Opkara à Parakou au Bénin, Tribune de l'eau $\mathrm{N}^{\circ} 642.1-12$.

[16] Gbaguidi, A. N. M, 2011. Etude de la distribution et des impacts en zone de culture cotonnière au Bénin: Cas des bassins versants de la rivière Agbado et des plans d'eau des réserves de biosphère de la Pendajri et $\mathrm{du} \mathrm{W}$ au Niger. Thèse de doctorat de l'Université d'Abomey-Calavi. 242p.

[17] Saizonou, V. M. M., 2012. 2012 'Caractérisation physico chimique et bactériologique des effluents de l'abattoir de Cotonou et leurs impacts sur la nappe phréatique : proposition de filière de traitement. (République du Bénin). Thèse de doctorat de l'Université d'Abomey - Calavi. 192p.

[18] Zogo, D., 2010. Etude de l'élimination du Fer et du Manganèse lors de la potabilisation de l'eau d'une retenue en cours d'euthrophisation: Cas de la retenue d'eau de l'Okpara à Parakou au Bénin. Thèse de doctorat de l'Université d'Abomey-Calavi. 205p. 
[19] Barroin, G., 2004. phosphore, azote, carbone...du facteur limitant au facteur de maitrise. Courrier de l'environnement de l'INRA n ${ }^{\circ} 52.25$ p.

[20] Biefert C. and Perraud R., 2011. Chimie de l'Environnement. Air, eau, sols, déchets. 2ème édition de boeck 478p.

[21] Dovonou, F., Aina, M., Boukari, M., et Alassane, A., 2011.
Pollution physico-chimique et bactériologique d'un écosystème aquatique et ses risques écotoxicologiques : cas du lac Nokoue au Sud Benin. International Journal of Biological and Chemical Sciences, 5 (August), 1590-1602.

[22] Alapini, A. L. G., 2009. Evaluation de la pollution du lac Nokoué par les métaux toxiques $(\mathrm{Pb}, \mathrm{Cd}$ et $\mathrm{Hg})$. Mémoire de DESS. CIFRED, Université d'Abomey-Calavi. 77 p. 